\title{
The Effects of Direct Written Corrective Feedback on Improvement of Grammatical Accuracy of High- proficient L2 Learners
}

\author{
Farahman Farrokhi \\ Faculty of Persian Literature and Foreign Languages, Tabriz University \\ The third floor, 29th Bahman Boulevard, Tabriz, Iran \\ Tel: 98-411-339-2161_ E-mail: ffarrokhi20@yahoo.co.uk \\ Simin Sattarpour (Corresponding author) \\ Faculty of Persian Literature and Foreign Languages, Tabriz University \\ The third floor, 29 Bahman Boulevard, Tabriz, Iran \\ Tel: 98-914-309-3494 E-mail: s.sattarpour@yahoo.com
}

\author{
Received: December 18, 2011 \\ Accepted: January 13, $2012 \quad$ Published: April 15, 2012 \\ doi:10.5430/wje.v2n2p49 \\ URL: http://dx.doi.org/10.5430/wje.v2n2p49
}

\begin{abstract}
The present article reports the findings of a study that explored(1) whether direct written corrective feedback (CF) can help high-proficient L2 learners, who has already achieved a rather high level of accuracy in English, improve in the accurate use of two functions of English articles (the use of 'a' for first mention and 'the' for subsequent or anaphoric mentions); and (2) whether there are any differential effects in providing the two different types of direct written CF (focused and unfocused) on the accurate use of these grammatical forms by these EFL learners. In this study, sixty high-proficient L2 learners formed a control group and two experimental groups. One experimental group received focused written $\mathrm{CF}$ and the other experimental group received unfocused written $\mathrm{CF}$, while the control group received no feedback. The statistical analyses indicated that both experimental groups did better than control group in the post-test, and moreover, focused group significantly outperformed unfocused one in terms of accurate use of definite and indefinite English articles. Overall, these results suggest that focused written CF is more effective than unfocused one, at least where English articles are concerned, in improving grammatical accuracy of high-proficient L2 writers and thus strengthens the case for teachers providing focused written CF.
\end{abstract}

Keywords: Written corrective feedback, Focused feedback, Unfocused feedback, English articles, Grammatical accuracy

\section{Introduction}

The extent to which written CF on linguistic errors can play a role in helping L2 writers improve the accuracy of their writing continues to be an issue of interest to researchers and teachers since Truscott (1996) mounted a case for its abolition. While there is growing empirical evidence that written CF can successfully target some types of linguistic error (e.g., Bitchener \& Knoch, 2008a; Chandler, 2003; Ferris, 2002; Sheen, 2007), it is unclear which feedback strategy is more effective. Additionally, the extent to which the linguistic proficiency level of an L2 writer might determine the effectiveness of written CF in treating certain grammatical structures has also been under-explored. Some attention has been given to investigating whether certain types of written CF may be more effective than others, but the findings are not conclusive. Addressing these issues will require time and commitment on the part of a number of researchers. The study being reported in this article contributes to this agenda by investigating the differential effects of direct focused and direct unfocused CF on the improvement of high-proficient learners' accurate use of two functions of English articles (the indefinite article ' $a$ ' as first mention and the definite article 'the' as second mention).

\section{Literature Review}

For L2 learners, writing in the target language is a painstaking job, and L2 teachers are required to help them improve their writing proficiency. Generally, overcoming the occurrence of errors depends on the way they are corrected and written feedback is an essential aspect of any English Language Writing course. Hyland (2003) has asserted that one of the major concerns of L2 writers is error-free work since their work may be evaluated in academic setting where 
accuracy is an important matter, so learners require and value feedback to their works. Also, Freedman (1987) believes that if students fail in well performance in writing, further feedback is necessary to help them take correct actions about their writing in order to improve it and reach an acceptable level of performance.

Since Truscott (1996) claimed that providing corrective feedback on L2 writing should be abandoned, debate about whether and how to give L2 learners feedback on their written grammatical errors has been of considerable interest to researchers and classroom practitioners. Some researchers (e.g., Kepner, 1991; Sheppard, 1992; Truscott, 2007) claim that grammar corrections do not have a positive effect on the development of L2 writing accuracy. According to the most extreme views, such as Truscott (2007), corrective feedback (CF), which indicates to learners that there is an error in their linguistic output, is seen as not only ineffective but also potentially harmful. In contrast, other researchers (e.g., Bitchener and Knoch, 2008a; Chandler, 2003; Ferris, 2002; Sheen, 2007) claim that CF is of value in promoting greater grammatical accuracy. There is now a growing body of literature on the efficacy of written CF for helping L2 writers improve the accuracy of their writing .On the one hand, there is evidence that written CF can help writers improve their written accuracy when asked to revise their texts (Ashwell, 2000; Fathman \& Whalley, 1990; Ferris, 1999, 2006; Ferris \& Roberts, 2001). On the other hand, there is mounting more recent evidence of the long-term effectiveness of written CF on accuracy improvement, revealed in the writing of new texts (Bitchener, 2008, 2009; Bitchener \& Knoch, 2008a, 2008b, 2010a; Bitchener, Young \& Cameron 2005, Chandler, 2003; Ellis, Sheen, Takashima \& Murakami, 2008; Robb, Ross \& Shortreed, 1986; Sheen, 2007; Sheen, Wright, \& Moldawa, 2009).

For instance, Ferris and Roberts (2001) investigated 72 university ESL students' abilities to self-edit their texts across three feedback conditions: (1) errors marked with codes; (2) errors underlined but not otherwise marked or labeled; (3) no feedback at all. They found that both groups who received feedback significantly outperformed the no-feedback group on the self-editing task but that there were no significant differences between the "codes" and "no-codes" groups. However, as mentioned before, more recently studies have examined the value of written CF by measuring progress in new pieces of writing. Bitchener et al. (2005), for example, investigated the extent to which different types of CF (direct $\mathrm{CF}$ with and without oral conferencing) influence the accuracy in new pieces of writing. They concluded that both types of direct CF had a significant impact on accuracy in new pieces of writing but that this was only evident for the definite article and past tense. What makes this issue even more controversial is the variety of strategies for carrying out written $\mathrm{CF}$ (e.g., direct, indirect, metalinguistic CF). It is not just a question of whether CF is effective but also which type is effective.

\subsection{Studies comparing different types of corrective feedback}

A range of studies have investigated whether certain types of written corrective feedback or combinations of different types are more effective than others. These studies have most often categorized feedback as either direct (explicit) or indirect (implicit). Direct corrective feedback may be defined as the provision of the correct linguistic form or structure by the teacher to the student above the linguistic error (Ferris, 2003, as cited in Bitchener \& Knoch, 2009). It may include the crossing out of an unnecessary word/phrase/morpheme, the insertion of a missing word/phrase/ morpheme, or the provision of the correct form or structure. Additional forms of direct feedback may include written meta-linguistic explanation (the provision of grammar rules and examples at the end of a student's script with a reference back to places in the text where the error has occurred). On the other hand, indirect corrective feedback is that which indicates that in some way an error has been made without explicit attention drawn (Ferris, 2003, as cited in Bitchener \& Knoch, 2009). This may be provided in one of four ways: underlining or circling the error; recording in the margin the number of errors in a given line; or using a code to show where the error has occurred and what type of error it is (Ferris and Roberts, 2001; Robb et al., 1986). Rather than the teacher providing an explicit correction, students are left to resolve and correct the problem that has been drawn to their attention.

In earlier years, a stronger case had tended to be made for the special value of providing students with indirect feedback rather than direct feedback. Lalande (1982) has explained that indirect feedback requires learners to engage in guided learning and problem solving and, therefore, promotes the type of reflection that is more likely to foster long-term acquisition. But as SLA researchers of oral L2 production have found, learners must first "notice" (Schmidt, 1990) that an error has been made. Once the error has been noted, indirect feedback has the potential to push learners to engage in hypothesis testing - a process which Ferris (2002) has suggested that may induce deeper internal processing and promote the internalization of correct forms and structures.

While not ignoring the value of indirect feedback, those more in favor of a direct approach have explained that teachers and students prefer direct feedback (e.g. Ferris \& Roberts, 2001). They suggest that it is more helpful to writers because it (1) reduces the type of confusion that they may experience if they fail to understand or remember the feedback they have been given (for example, the meaning of error codes used by teachers); (2) provides them with information to help 
them resolve more complex errors (for example, syntactic structure and idiomatic usage); (3) offers more explicit feedback on hypotheses that may have been made; and (4) is more immediate. More recently, Chandler (2003) has explained that the greater cognitive effort expended when students are required to use indirect feedback to make their own corrections is offset by the additional delay in knowing whether their own hypothesized correction is in fact correct.

Studies that have investigated the effects of different types of written CF can be classified according to those that have compared (1) direct and indirect types of feedback; (2) different types of indirect feedback; and (3) different types of direct feedback. To mention some of the studies in the first group, Lalande (1982) reported an advantage for indirect feedback; Robb, Ross, and Shortreed (1986) and Semke (1984) reported no difference between the two approaches; and Chandler (2003) reported positive findings for both direct and indirect feedback. It is one of the reasons for being tentative in making firm conclusions from this conflicting and limited body of evidence. Moreover, limitations in the design and execution of these studies (see Bitchener, 2008; Guenette, 2007 for discussion of these issues) and differences in their contexts and in the proficiency level of their participants make it difficult to assess the value of the claims that are made. It should also be noted that most of these studies did not look at new pieces of writing, so they provide no information about the long-term effectiveness on written accuracy. Further research is therefore required in this area.

Another group of studies has investigated the effectiveness of different types of indirect feedback (coded and uncoded). None of these studies (e.g. Ferris\&Roberts, 2001; Robb et al., 1986) found any difference between coded and uncoded options. However, only the study by Robb et al. (1986) examined the effect of corrective feedback on new pieces of writing over time. The other studies only measured the effect of corrective feedback on text revisions.

Moreover, several recent studies (e.g. Bitchener et al., 2005; Bitchener, 2008; Bitchener \& Knoch, 2010b) have examined the relative effectiveness of different types of direct CF on improved accuracy. For instance, Bitchener et al. (2005) compared the effect of different direct feedback combinations typically practised in advanced proficiency classroom settings: (1) direct error correction plus oral metalinguistic explanation in 5 minute one-on-one conferences; (2) direct error correction; and (3) no corrective feedback. They found that those in group one outperformed both groups two and three for the past simple tense and the definite article but found no such effect for prepositions. They suggested that the addition of oral metalinguistic explanation may have been the crucial factor in facilitating increased accuracy.

Additonally, Bitchener (2008) investigated the effectiveness of other direct feedback combinations: (1) direct error correction with written metalinguistic explanation and oral meta-linguistic explanation; (2) direct error correction with written meta-linguistic explanation; (3) direct error correction; and (4) no corrective feedback. Feedback was provided on only two functional uses of the English articles (the indefinite article "a" for first mention and the definite article "the" for subsequent or anaphoric mentions). Groups one and three outperformed the control group while group two only just failed to do so. When the study was extended (Bitchener \& Knoch, 2008a, 2009) to include an additional 69 learners, no difference was observed between the same three treatment combinations. Thus, it is possible that the larger sample size eliminated the difference in effect between group two and the other two treatment groups in the first study (Bitchener, 2008).

Another study by Bitchener and Knoch (2010b), investigating over a 10 month period the relative effectiveness of the same four different feedback approaches, found that each of the groups who received one of the treatment options outperformed the control group and that there was no difference in effectiveness between the three treatment groups, suggesting therefore that none of the written CF options was any more effective than another. The special significance of this finding was its investigation over a 10 month period and therefore its longitudinal measurement of the effectiveness of different types of CF on accuracy retention.

A further distinction that needs to be examined is between 'unfocused' and 'focused' CF. These two types of written CF can be provided either directly or indirectly, but nearly all the studies comparing the effects of these two CF types have used them in direct way. Sheen (2007) examined the effects of focused CF on the development of 91 adult ESL learners' accuracy in the use of two types of articles ('the' and 'a'). The study included a direct only group (the researcher indicated errors and provided correct forms), a direct-metalinguistic group (the researcher indicated errors, provided correct forms, and supplied metalinguistic explanations), and a control group. The effectiveness of the CF was measured on pretests, posttests, and delayed posttests. Sheen found that both direct CF groups outperformed the control group. She explained this finding by pointing out that the feedback supplied to the students with the correct form was limited to two linguistic forms (i.e., articles 'the' and 'a'), which made the processing load manageable for them.

To date only a few numbers of studies have focused on comparing the effects of focused and unfocused CF. For the first time, Ellis, Sheen, Takashima and Murakami (2008) compared the effects of direct focused and direct unfocused CF on the accurate use of English definite and indefinite articles and reported that both focused and unfocused CF groups 
gained from pre-test to post-tests on both an error correction test and on a test involving a new piece of narrative writing and also outperformed a control group, which received no correction, on the second posttest. Therefore, the CF was equally effective for the focused and unfocused groups. However, as mentioned by Sheen et al. (2009), one of the methodological problems with this study, acknowledged by the authors, was that the focused and unfocused CF were not sufficiently distinguished (i.e., article corrections figured strongly in both) and another limitation of this study was that their measure of learning involved just one structure - articles (i.e., they did not examine whether focused CF had any effect, on the accuracy of structures not targeted by the CF).

To overcome some of the limitations of previous study, Sheen, Wright, \& Moldawa (2009), using six intact adult ESL intermediate classes totaling 80 students, investigated the effects of the direct focused and direct unfocused approaches on both single grammatical target (articles) and on a broader range of grammatical structures (i.e., articles, copula 'be', regular past tense, irregular past tense and preposition). They had four groups in this study consisting: focused written CF group, unfocused written CF group, writing Practice Group and Control Group. Interestingly, they reported that focused CF group achieved the highest accuracy scores for both articles and the other four grammatical structures. Therefore, they concluded that unfocused $\mathrm{CF}$ is of limited pedagogical value while focused $\mathrm{CF}$ can contribute to grammatical accuracy in L2 writing.

To date, the findings of research on feedback types have revealed some interesting patterns, but the inconsistency of the findings makes it clear that more research is needed. Much of the available research has been done with lower proficient or intermediate learners, so the extent to which the effectiveness of written CF is dependent upon the proficiency level of an L2 writer is under question. As Ellis (2008) has stated, "the effectiveness of direct and indirect feedback is likely to depend on the current state of the learners' grammatical knowledge" (p.355). Therefore, further research that avoids the design and execution shortcomings of earlier comparisons between different types of CF is also required to see (1) if there is a difference in effect between the two specific types of written CF (focused and unfocused) and (2) if the proficiency level of L2 learners has a further effect on the findings of these investigations. Therefore, the present study aimed to investigate1) the effects of direct written CF on accurate use of targeted grammatical forms (English articles) by high-proficient L2 learners; and 2) the differential effects of focused and unfocused direct written $\mathrm{CF}$ on grammatical accuracy of those learners.

\section{Method}

\subsection{Research Questions and Hypotheses}

RQ1: Does the accuracy of high-proficient L2 learners in the use of two functions of the English articles improve as a result of direct written CF?

H01: The accuracy of high-proficient L2 learners in the use of two functions of the English articles doesn't improve as a result of direct written CF.

H1: The accuracy of high-proficient L2 learners in the use of two functions of the English articles improve as a result of direct written $\mathrm{CF}$.

RQ2: Are there any significant differences in the effects of focused and unfocused direct written CF on accurate use of grammatical forms by high-proficient EFL learners?

H02: There are no significant differences in the effects of focused and unfocused direct written CF on accurate use of grammatical forms by high-proficient EFL learners.

$\mathrm{H} 2$ : There are significant differences in the effects of focused and unfocused direct written $\mathrm{CF}$ on accurate use of grammatical forms by high-proficient EFL learners.

\subsection{Participants}

The study was conducted in Iran with 60 high-proficient Iranian EFL learners including 26 males and 34 females with age range of 18-35. Since all the participants were university students, they had the experience of studying English in junior high school and high school. In addition, most of the learners had passed general English course (i.e. a compulsory 3-hour credit course) in the first or second semester of university in all majors. Additionally, in order to guarantee the learners' proficiency level, they also took a TOEFL proficiency test. Then the learners were randomly assigned to three groups, 20 learners in each group, two experimental groups and one control group. The experimental groups consisted of (1) a focused written CF group, and (2) an unfocused written CF group.

\subsection{Instruments}

The first instrument utilized in the present study was an actual TOEFL proficiency test administered in 2004 by ETS in 
order to assign participants into high proficiency level. The other instruments were five short fables based on Aesop.'s fables which were used as written narrative tasks. Additionally, to examine the effects of the two types of treatments on learners' use of the indefinite article (for first mention) and the definite article (for anaphoric reference), two different picture compositions taken from Byrne (1967) were used as narrative writing tests. One of the tests was administered in pre-test session and the other one in post-test session. These picture compositions consisted of six pictures shown sequentially and the learners were asked to look at them and write a story.

\subsection{Choice of Target Structures}

Drawing on Sheen (2007), who investigated the learning of English articles (the indefinite article 'a' as first mention and the definite article 'the' as second mention); the current study chose the same target structure for the focused CF treatment. The unfocused CF treatment in this study targeted the following five linguistic features:(1) English articles, (2) copula 'be', (3) regular and irregular past tense, (4) third person 's', and (5) prepositions (e.g., at, in, on). There are some reasons for choosing these structures as target structures of this study. First, they are among the frequently observed errors in EFL learners' writings. Second, obligatory occasions for the use of articles appear regularly in certain types of discourse (e.g. narratives) and thus provide a basis for reliable analysis of learners' accuracy of use. Third, articles are already partially acquired (i.e. used but not always correctly) and are not an entirely new structure. Based on Ellis, Sheen, Murakami and Takashima(2008), CF will be more effective in assisting learners to develop control over structures they have began to acquire than in helping them acquire entirely new linguistic forms that they may not be ready to acquire. Fourth, articles constitute a problem for L2 learners, especially those learners whose L1 does not contain both definite and indefinite articles (e.g. the Iranian learners that were the participants of the study).

\subsection{Procedures}

In this quasi-experimental study after assigning the participants into preferred proficiency level by administering a TOEFL test, they were classified into three groups, two experimental groups and one control group. Then, a week prior to starting the treatment sessions, a narrative writing test (picture composition) as a pretest was given to all participants in order to be sure of their homogeneity and to measure their writing proficiency in use of the indefinite article (for first mention) and the definite article (for anaphoric reference) at the beginning of the study. The participants were asked to look at the pictures and write a story in details about 150-200 words within a given time (15-20 minute).

Afterwards, over the next three weeks, all three groups completed five written narrative tasks in every other session, each of which followed by a CF treatment session in the following class. The narrative tasks involved reading and then rewriting fables. The first experimental group received focused CF; the second experimental group received unfocused $\mathrm{CF}$, while the control group received no feedback. The grammatical target for the focused group was the use of English definite and indefinite articles whereas the target for the unfocused CF group included the following five grammatical features: :(1) English articles, (2) copula 'be', (3) regular and irregular past tense, (4) third person's', and (5) prepositions (e.g., at, in, on).

Finally, one session after receiving CF for the last writing task, the learners were given another narrative writing test (picture composition) as a post-test. Writing test scores were calculated by means of obligatory occasion analysis (Ellis $\&$ Barkhuizen, 2005) in order to measure the differential effects of our treatments on the acquisition of the accurate use of the indefinite article (for first mention) and the definite article (for anaphoric reference). That is, all obligatory occasions for the use of 'a' (first mention) and 'the' (anaphoric reference) were identified. Each occasion was then checked to see whether or not the correct article had been supplied. Non-suppliance took the form of either omission of any article or of the use of the wrong article (e.g. 'the' instead of 'a'). Also, following Ellis et al. (2008), in contexts requiring the indefinite article, the use of either 'a' or 'an' was taken as correct irrespective of which form of the indefinite article the context required. An accuracy score was then calculated for each learner as a percentage of the ratio of the total number of correctly supplied articles to the total number of obligatory occasions. For example, on any one text, three correct uses of the targeted form from ten obligatory occasions meant a 30\% accuracy rate.

\section{Results}

In Table 1, the descriptive statistics (the mean scores and standard deviations ) for the two experimental groups and the control group at two different testing times (pre-test and post-test) are shown. The mean scores of the learners on the post-test are different from each other across the three groups unlike the pre-test mean scores which are very close to each other. These obtained results indicate that after receiving the treatment of the study, the three groups showed dissimilar performances; therefore, our treatment had some effects on the improvement of the learners' accuracy performance but not the same effect.

<Table 1 about here> 
Since descriptive statistics alone are not strong enough to reject or accept the second hypothesis, a one-way ANOVA analysis was applied to see whether the differences across the three groups are statistically significant or not. The results shown in Table 2 indicate that the level of computed significance or $p$ value is less than the level of significance set in this analysis $(p=0.032, \alpha=0.05, p<\alpha)$. Therefore, providing the two different types of feedback had significantly different effects on written accuracy performance of high-proficient learners in the use of definite and indefinite English articles. Therefore, the second null hypothesis is also rejected and consequently the alternative hypothesis is accepted.

\section{$<$ Table 2 about here>}

Having applied the One-way ANOVA, the researcher acknowledged that at least two of the individual means are significantly different from each other. However, the most important point is that which ones? In order to determine the exact location of mean differences, a post hoc analysis had to be applied. Therefore, Tukey's post hoc pair-wise comparison (with an alpha level of .05) was performed to see the difference between which groups is statistically significant. These results indicated that on the post-test, participants in focused CF group significantly outperformed those in the unfocused CF and control groups.

Figure 1 provides a visual representation of the comparison between mean scores of the two tests (pre-test and post-test) for each group. This comparative graphical representation depicts the first place of learners' language ability in targeted structures from which they started the study and the patterns of their improvement from the pre-test to the post-test. It should be mentioned that all the three groups even the control group improved from the pre-test to the post-test, but it can be seen clearly in Figure 1 that both focused and unfocused CF groups did better than the control group on the post-test, and moreover, the focused CF group outperformed the unfocused CF group. To summarize, these results led the researcher to conclude that although providing feedback has positive effect on high-proficient learners' accuracy performance in general, the focused written CF is more effective than the unfocused written CF.

<Figure 1 about here>

\section{Discussion}

The first research question of the study concerned whether written CF on two targeted functional uses of the English article system enabled high-proficient L2 writers, who had already achieved a reasonable level of accuracy, to further improve this level of achievement. It was found that both experimental groups (focused and unfocused) showed better accuracy performances on the post-test than the control group.

Concerning the general effects of written CF apart from its specific type, the results of this study corroborate those of recent studies on article use with lower proficiency writers (Bitchener, 2008; Bitchener\&Knoch, 2008a, 2008b, 2010; Sheen, 2007; Sheen et al., 2009). In each of these studies, the effectiveness of written CF was evident immediately after it had been provided in the post-test pieces of writing. Given the high level of accuracy in the pre-test piece of writing in the present study, we were unsure whether further gains in accuracy would result or not. As the study reveals, all two treatment groups (focused and unfocused written CF groups) outperformed the control group in the post-test. Therefore, concerning the accurate use of two targeted functional uses of the English article system by high-proficient L2 writers, the results of this study are in line with the study of Bitchener and Knoch (2010b) who found that advanced L2 writers were able to make further gains in accuracy as a result of targeted written CF. In this respect, the findings of their study informed us that "there is potential for written CF to also be effective in targeting certain types of errors made by advanced L2 writers, even when their existing levels of accuracy are quite high, and that these can be targeted successfully with one feedback treatment"(p. 215).

The second research question of the study investigated the differential effects of direct focused and direct unfocused written CF on accurate use of English articles by high-proficient writers. The results showed that although both focused and unfocused CF groups did better than the control group, focused CF group outperformed both. Therefore, it can be concluded that first of all, providing written corrective feedback is an effective way for responding to high-proficient learners' written performance in general, and secondly that focused written CF has more positive effect on these learners' acquisition of the targeted structures than the unfocused written CF.

Concerning the differential effects of different types of direct written CF, earlier studies of the effectiveness of different types of written CF (Chandler, 2003; Lalande, 1982; Robb et al., 1986; Semke, 1984) have produced essentially inconclusive results on the relative merits of direct and indirect CF. On the other hand, Bitchener and Knoch (2010b) revealed clear evidence of the greater effectiveness of direct forms of written CF when measured over time in delayed post-test. They reported that both types of direct written CF (written metalinguistic explanation and written meta-linguistic feedback with oral form-focused instruction) were significantly more effective in helping advanced L2 writers retain the accuracy gains they had made in the immediate post-test piece of writing, but those who had received 
indirect written CF were unable to retain the gains they had made in the immediate post-test piece of writing.

The superior long-term effect of providing L2 writers with meta-linguistic feedback was also reported by Sheen (2007) in her study of intermediate L2 writers. Sheen compared different types of direct feedback and found in her delayed post-test writing task that her L2 writers who received meta-linguistic explanation retained the gains they had made in their immediate post-test writing task, but that those who received direct error correction alone did not retain their level of performance. On the other hand, it is interesting to note that Bitchener and Knoch (2008a, 2008b, 2010), also studying lower proficiency writers, found no difference between writers who received different types of direct feedback. Thus, it is clear that further research is needed to clarify the relative effectiveness of all types of indirect and direct feedback when given to L2 writers of different proficiency levels.

Therefore, due to inconclusive results of the previous studies comparing different types of direct written CF, the present study compared two specific types of direct written CF (focused and unfocused) in high proficiency level. In line with the results of Sheen, Wright and Moldawa's (2009) study, which was done in intermediate proficiency level, it was found that focused CF was more effective than unfocused one. According to Sheen et al. (2009), one reason that unfocused CF was not effective is that when the correction addresses a range of grammatical errors, learners are unable to process the feedback effectively, and even if they attend to the corrections, they are unable to work out why they have been corrected. Han (2002), has also argued that "a consistent focus on one aspect of L2 use" is one of the key conditions for recasts (as one type of $\mathrm{CF}$ ) to have an effect on acquisition. Finally, Sheen et al. (2009) has pointed out the probable reasons of differential effectiveness of focused and unfocused $\mathrm{CF}$ as follows:

Focused CF may enhance learning by helping learners to (1) notice their errors in their written work, (2) engage in hypothesis testing in a systematic way and (3) monitor the accuracy of their writing by tapping into their existing explicit grammatical knowledge. In contrast, unfocused CF runs the risk of (1) providing CF in a confusing, inconsistent and unsystematic way and (2) overburdening learners. (p. 567)

\section{Conclusions and Implications of the Study}

From the pedagogical point of view, these findings are good news for L2 teachers since they indicates that, with providing direct written CF, even high-proficient L2 learners can further increase their mastery of linguistic features that continue to appear as errors in their written texts. Additionally, as this study revealed, teachers should feel confident that providing error correction alone on specific functional uses of limited number of rule-based features (focused $\mathrm{CF}$ ) is more effective and helps high-proficient learners to improve better in accurate use of English articles than correcting all of the existing errors from different grammatical features in learners' one piece of writing. Although further research would be needed as confirmation, we may also find that other, rule-based linguistic items can be treated effortlessly in the same way. On the evidence provided in this study, we would not want to generalize this finding to other linguistic structures or forms, until further research investigates the effectiveness of written CF in treating those structures and forms.

\section{References}

Ashwell, T. (2000). Patterns of teacher response to student writing in a multiple-draft composition classroom: Is content feedback followed by form feedback the best method? Journal of Second Language Writing, 9 (3), 227 - 257. http://dx.doi.org/10.1016/S1060-3743(00)00027-8

Bitchener, J. (2008). Evidence in support of written corrective feedback. Journal of Second Language Writing, 17, 102-118. http://dx.doi.org/10.1016/j.jslw.2007.11.004

Bitchener, J. (2009). Measuring the effectiveness of written corrective feedback: A response to "Overgeneralization from a narrow focus: A response to Bitchener (2008)". Journal of Second Language Writing, 18(4), $276-279$. http://dx.doi.org/10.1016/j.jslw.2009.06.001

Bitchener, J., \& Knoch, U. (2008a). The value of written corrective feedback for migrant and international students. Language Teaching Research Journal, 12(3), 409-431. http://dx.doi.org/10.1177/1362168808089924

Bitchener, J., \& Knoch, U. (2008b). The value of a focused approach to written corrective feedback. ELT Journal, 63(3), 204-211. http://dx.doi.org/10.1093/elt/ccn043

Bitchener, J., \& Knoch, U. (2009). The relative effectiveness of different types of direct written corrective feedback. System, 37(2), 322-329. http://dx.doi.org/10.1016/j.system.2008.12.006 
Bitchener, J., \& Knoch, U. (2010a). The contribution of written corrective feedback to language development: A ten month investigation. Applied Linguistics, 31(2), 193-214. http://dx.doi.org/10.1093/applin/amp016

Bitchener, J., \& Knoch, U. (2010b). Raising the linguistic accuracy level of advanced L2 writers with written corrective feedback. Journal of Second Language Writing, 19, 207-217. http://dx.doi.org/10.1016/j.jslw.2010.10.002

Bitchener, J., Young, S., \& Cameron, D. (2005). The effect of different types of corrective feedback on ESL student writing. Journal of Second Language Writing, 14, 191-205. http://dx.doi.org/10.1016/j.jslw.2005.08.001

Byrne, D. (1967). Progressive picture compositions: Pupils’ Book. Longman, London.

Chandler, J. (2003). The efficacy of various kinds of error feedback for improvement in the accuracy and fluency of L2 student writing. Journal of second language writing, 12(3), 267-296. http://dx.doi.org/10.1016/S1060-3743(03)00038-9

Ellis, R. (2008). A typology of written corrective feedback types. ELT Journal, 63(2), 97-107. http://dx.doi.org/10.1093/elt/ccn023

Ellis, R., \& Barkhuizen, G. (2005). Analyzing Learner Language. Oxford: Oxford University Press.

Ellis, R., Sheen, Y., Murakami, M., \& Takashima, H. (2008). The effects of focused and unfocused written corrective feedback in an English as a foreign language context. System, 36, 353-371. http://dx.doi.org/10.1016/j.system.2008.02.001

Fathman, A., \& Whalley, E. (1990). Teacher response to student writing: focus on form versus content. In B. Kroll (Ed.), Second Language Writing: Research insights for the classroom (pp. 178-190). Cambridge: Cambridge University Press.

Ferris, D. R. (1999). The case for grammar correction in L2 writing classes. A response to Truscott (1996). Journal of Second Language Writing, 8, 1-10. http://dx.doi.org/10.1016/S1060-3743(99)80110-6

Ferris, D. R. (2002). Teaching students to self-edit. In J. C. Richards \& W. A. Renandya (Eds.), Methodology in language teaching: An anthology of current practice (pp. 315-320). Cambridge: Cambridge University Press.

Ferris, D. R. (2006). 'Does error feedback help student writers? New evidence on short- and long-term effects of written error correction. In K. Hyland \& F. Hyland (Eds.). Feedback in second language writing: Contexts and issues. Cambridge: Cambridge University Press.

Ferris, D. R., \& Roberts, B. (2001). Error feedback in L2 writing classes: How explicit does it need to be? Journal of Second Language Writing, 10, 161-84. http://dx.doi.org/10.1016/S1060-3743(01)00039-X

Freedman, S. (1987). Response to student writing. Urbana: National Council of Teachers of English.

Guenette, D. (2007). Is feedback pedagogically correct? Research design issues in studies of feedback on writing. Journal of Second Language Writing, 16, 40-53. http://dx.doi.org/10.1016/j.jslw.2007.01.001

Han, Z. H. (2002). A study of the impact of recasts on tense consistency in L2 output. TESOL Quarterly, 36, 543-572. http://dx.doi.org/10.2307/3588240

Hyland, K. (2003). Second language writing. New York: Cambridge University Press.

Kepner, C. G. (1991). An experiment in the relationship of types of written feedback to the development of second-language writing skills. Modern Language Journal, 75, 305-313. http://dx.doi.org/10.2307/328724

Lalande, J. (1982). Reducing composition error: An experiment. Modern Language Journal, 66, 140-149. http://dx.doi.org/10.2307/326382

Robb, T., Ross, S., \& Shortreed, I. (1986). Salience of feedback on error and its effect on EFL writing quality. TESOL Quarterly, 20, 83-93. http://dx.doi.org/10.2307/3586390

Schmidt, R. (1990). The role of consciousness in second language learning. Applied Linguistics, 11, 206-226. http://dx.doi.org/10.1093/applin/11.2.129

Semke, H. (1984). The effects of the red pen. Foreign Language Annals, 17, 195-202. http://dx.doi.org/10.1111/j.1944-9720.1984.tb01727.x

Sheen, Y. (2007). The effect of focused written corrective feedback and language aptitude on ESL learners' acquisition of articles. TESOL Quarterly, 41, 255-283. 
Sheen, Y., Wright, D., \& Moldawa, A. (2009). Differential effects of focused and unfocused written correction on the accurate use of grammatical forms by adult ESL learners. System, 37, 556-569. http://dx.doi.org/10.1016/j.system.2009.09.002

Sheppard, K. (1992). Two feedback types: do they make a difference? Regional English Center Journal, 23, $103-110$.

Truscott, J. (1996). The case against grammar correction in L2 writing classes. Language Learning, 46, 327-369. http://dx.doi.org/10.1111/j.1467-1770.1996.tb01238.x

Truscott, J. (2007). The effect of error correction on learners' ability to write s accurately. Journal of Second Language Writing, 16, 255-272. http://dx.doi.org/10.1016/j.jslw.2007.06.003

Table 1. Descriptive statistics for the narrative writing tests (HP)

\begin{tabular}{|l|l|l|l|l|l|}
\hline Groups & N & \multicolumn{2}{l|}{ Pre-test } & \multicolumn{2}{l|}{ Post-test } \\
\hline & & $\mathrm{M}$ & $\mathrm{SD}$ & $\mathrm{M}$ & $\mathrm{SD}$ \\
\hline Focused & 20 & 56.02 & 9.46 & 81.49 & 10.97 \\
\hline Unfocused & 20 & 54.5 & 7.63 & 64.12 & 7.12 \\
\hline Control & 20 & 52.81 & 8.97 & 58.96 & 8.28 \\
\hline
\end{tabular}

Table 2. Comparing Post-test Mean Scores (HP)

ANOVA

\begin{tabular}{|l|c|c|c|c|c|}
\hline & Sum of Squares & df & Mean Square & F & Sig. \\
\hline Between Groups & 5573.466 & 2 & 2786.733 & 34.840 & .032 \\
\hline Within Groups & 4559.172 & 57 & 79.985 & & \\
\hline Total & 10132.638 & 59 & & & \\
\hline
\end{tabular}

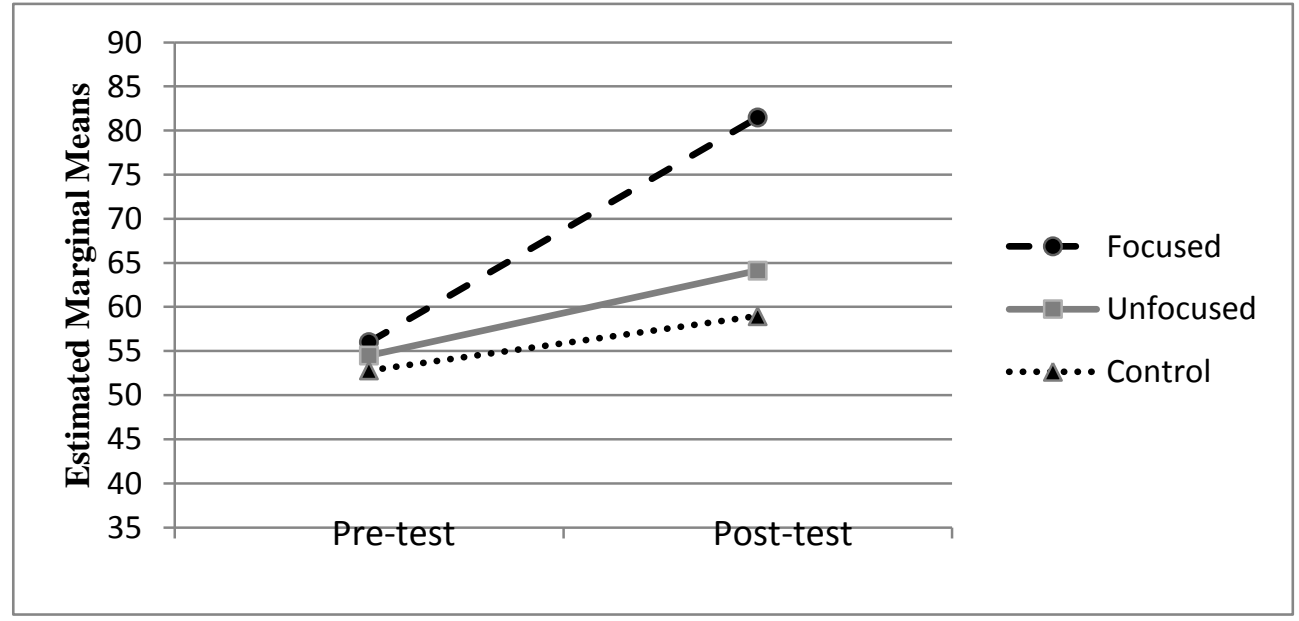

Figure 1. Comparing Pre-test and Post-test Mean Scores 